\title{
The Effect of Market Structure on Bank Performance in Central Java
}

\author{
Imanuel Madea Sakti \\ Universitas Kristen Satya Wacana, Indonesia \\ imanuel.sakti@uksw.edu
}

\begin{abstract}
The research on the Structure-Conduct-Performance (SCP) hypothesis in the banking industry has been done many times, including in Indonesia. However, it still focuses on commercial banks. This research aims to examine the relationship between market structure and bank performance by involving commercial banks and rural banks (Bank Perkreditan Rakyat/BPR) when they are in the same market in the regency/city level. It uses panel data from 565 banks in Central Java: 261 BPR and 304 Commercial Banks, divided into 34 regencies/cities during 2012-2016. Independent variables involve market concentration and market share which is also as moderating variable, and the dependent variable is bank performance. The hypotheses are examined by multiple linear regression with a random effect model. In general, the results support that the market structure has a significant positive effect on bank performance. Another result has found no collusive behavior among dominant banks.
\end{abstract}

Keywords: structure-conduct-performance, commercial bank, rural bank, market structure, bank performance

\section{Pengaruh Struktur Pasar terhadap Kinerja Bank di Jawa Tengah}

\begin{abstract}
Abstrak
Penelitian mengenai hipotesis Structure-Conduct-Performance (SCP) pada industri perbankan telah banyak dilakukan, termasuk di Indonesia. Namun, penelitian tersebut hanya berfokus pada bank umum saja. Penelitian ini bertujuan untuk menguji hubungan antara struktur pasar dan kinerja bank dengan melibatkan bank umum dan Bank Perkreditan Rakyat (BPR) ketika berada di pasar yang sama di tingkat kabupaten/kota. Penelitian ini menggunakan data panel terdiri dari 565 bank di Jawa Tengah: 261 BPR dan 304 Bank umum, yang terbagi ke dalam 34 kabupaten/kota selama tahun 2012-2016. Variabel independen yaitu konsentrasi pasar dan pangsa pasar yang sekaligus sebagai variabel moderasi, dan variabel dependen adalah kinerja bank. Hipotesis diuji menggunakan regresi linier berganda dengan random effect model. Secara umum, hasil mendukung bahwa struktur pasar berpengaruh positif signifikan terhadap kinerja bank. Hasil lainnya menunjukkan tidak terdapat perilaku kolusif di antara bank-bank besar.
\end{abstract}

Kata kunci: . structure-conduct-performance, bank umum, BPR, struktur pasar, kinerja bank.

\section{INTRODUCTION}

Research on the banking industry in Indonesia has been widely carried out because banking as an intermediary institution plays an important role in the country's economy. In 2018, the percentage of the assets of the banking industry against the assets of the financial sector amounted to 77.28 percent while the rest were assets of the non-bank financial services institutions (NBFI). Total banking assets on commercial banks reached Rp 7,387,144 (in billion) and rural banks (Bank Perkreditan Rakyat/BPR) reached Rp 125,945 (in billion), more dominant than the stock market capitalization value of $R p 7,052,389$ (in billion) (OJK, 2017). Thus, the banking industry will be expected to maintain stability and efficiency, driving the country's economic growth.

The banking industry is both closely regulated and monitored because of the risk of bank failure that could contribute to the systemic impact of the economy, in addition, to 
create healthy competition to boost bank performance. One of the factors affecting bank performance is the market structure of the banking industry. The market structure has two main elements, namely market concentration and market share. The market concentration is defined as market mastery by one or several companies (banks) in an industry, while the market share is defined as the size of the market demand that the company (bank) can serve. A high market concentration can encourage anti-competitive (unhealthy competition) in the pursuit of profit by one or some of the largest banks, whereas companies (banks) with large market shares have the market power to achieve supernormal profits.

The relationship between market structure and bank performance is generally explained by the Structure-Conduct-Performance hypothesis (SCP) and Efficient Structure hypothesis (ES) (Berger \& Hannan, 1989; Demsetz, 1973; Peltzman, 1977; Smirlock, 1985). The SCP hypothesis explains that companies can make higher profits (monopoly profits) in concentrated markets by utilizing oligopolistic behavior and collusion arrangement among companies in that industry. According to this hypothesis, the positive correlation between profitability and market concentration suggests that the banking market is not perfectly competitive. On the other hand, the ES hypothesis asserted that the higher profits companies produce are caused by company performance that more efficient than others so that increasing their market size and market power. Thus, the SCP hypothesis stresses market collusion as a cause of the company's high profits, vice versa, the ES hypothesis stresses the operational efficiency of superior companies as a cause (Sathye, 2005).

Research on the topic of market structure and bank performance mostly involves commercial banks on a national aggregate basis, whereas in Indonesia there are two types of banking, i.e. commercial banks and rural banks (BPR). Even though they have different operational areas, both have slices of the market and the products offered. To view these phenomena, this research focuses on the relationship between market structure and bank performance by involving commercial banks and BPR in the same market, Central Java Province, because: the largest share of BPR in terms of assets $(22.30 \%)$, third party funds (24.84\%), loans (23.21\%), the second-largest number of BPR offices (1,519 offices), the third-largest number of BPR (253 BPR), and the second-largest number of regencies and cities nationally. Also, Hafidz et al. (2013) state that competition between rural banks and commercial banks only occurs in the same operational area.

Commercial banks are considered to be superior in micro-credit services with relatively lower interest rates to obtain high profits supported by better financial and managerial capabilities. Whereas rural banks are considered superior in high-interest deposit services and the closeness and reach of customers in small areas. Deyoung et al. (2004) argue that small banks (rural banks) or often called community banks have a competitive advantage that is different from large banks. Small banks tend to have more limited services, local customers, and retail-oriented, while large banks are more businessoriented. The existence of some of these differences can encourage the creation of a different competition environment so it is interesting to study, how the market structure affects the performance of commercial banks and rural banks when viewed with the SCP hypothesis. 
Furthermore, the SCP hypothesis explains the relationship among market structure, company behavior, and company performance as a causal relationship. Structure focuses on market conditions where the company competes with other competitors and interacts with consumers, behavior (conduct) focuses on various policies or strategies of the company and competitors to dominate the market, and performance focuses on the output of various policies or strategies implemented by the company before.

Bain (1951) states that the market structure is determined by exogenous conditions that will affect the company's behavior and performance. In the SCP hypothesis, exogenous variables affect the market structure, while company behavior and performance are influenced by endogenous variables. This concept assumes that high market concentration will harm consumers, for example through anti-competitive behavior. A concentrated market can produce market power in the banking sector, banks can obtain monopoly profits by offering lower deposit rates and providing higher loan interest rates. This is following Heggestad \& Mingo (1976) that the market power of banks will determine the aggressiveness of banks in competing for deposits (third party funds/TPF). The market power of an individual bank increases with the level of monopoly in its market and its size relative to the market. The greater the market share or the more concentrated market, the greater the bank's control over the prices and the services it offers.

Neuberger (1997) suggests a new SCP hypothesis that has been adapted to the banking industry, where all variables are endogenous because the variables in market structure, company behavior, company performance and market conditions, as well as public policy, have dependencies with each other. The SCP hypothesis is the most widely used model because it provides an overview of the market structure that affects competition and behavior between companies in the industry. In the banking industry, the market structure explains the number of banks that provide services and enter the industry. Whereas conduct explains bank behavior in the industry, and performance describes the quantity and quality of goods and services provided by banks in the industry (Nabieu, 2013).

The market structure of the industry will determine the company behavior which will further determine the company performance in the industry (Mason, 1939). High market concentration can drive company performance and anti-competitive behavior among large companies. This is a source of the emergence of market power to gain supernormal profits (Berger \& Hannan, 1989). The higher the market concentration, the higher the company performance.

Previous research on the relationship between market structure and bank performance shows mixed results. Smirlock (1985) uses market concentration as a measure of the market structure while market share is used as a measure of company efficiency. The results show that is no positive effect of market concentration found on bank performance, but market share has a positive effect on bank performance in the United States banking industry. A high market share is interpreted as a signal that the company operates efficiently (low cost) so that the bank gets a large market share. So this research supports the ES hypothesis more than the SCP hypothesis. 
In contrast, Tregenna (2009) examines the effect of market structure on bank performance in the United States by including the pre-crisis period 1994 to 2005. The crisis tends to lead to an increase in bank concentration caused by bank consolidation (mergers and acquisitions) so that the analysis of the relationship between market concentration and bank performance is very relevant. Panel data is used to examine the effect of market concentration, market power, bank size, and operational efficiency on bank performance. The results show that operational efficiency is not found as a determinant factor in bank performance, which means that bank's high profit is not the result of operational efficiency but the influence of market concentration that increases bank performance (ROA and $\mathrm{ROE}$ ), so this research supports the SCP hypothesis.

In Asia, Bhatti \& Hussain (2010) find a positive effect of market concentration on bank performance in Pakistan thus this research supports the SCP hypothesis. While AbRahim \& Chiang (2016); Rettab et al. (2010) find that banking performance in Gulf countries and Malaysia are more influenced by efficiency performance, especially after mergers and acquisitions. According to Demsetz (1973); Peltzman (1977) that companies with superior performance such as technology and managerial capabilities are relatively more efficient than other companies so that they obtain greater profits by maximizing the rate of return. Accordingly, the company will have a larger market share which in turn leads to high concentration in the market, so that, efficiency is the main weapon in market concentration.

Following Berger (1995); González et al. (2019); Irawati (2017), in the SCP model, there is a Relative Market Power (RMP) hypothesis that in a concentrated market, a dominant bank can obtain high profits through its market power. Market share reflects the market power realized by banks, so banks with large market shares can set prices higher than other banks, to obtain higher profits. The greater the market share, the higher the bank's profit which means the bank has better performance (Garza-Garcia, 2012). Whereas research by Chaerani et al. (2019) concerning the market structure and performance of commercial banks in Indonesia shows that market share has a positive effect on bank performance. This shows that banks can dominate the market and improve their performance not from maximizing monopoly power but from the ability to diversify products.

Inconsistent findings on the relationship of market structure and bank performance in various countries make this topic still relevant to be a concern, especially in developing countries with different market structure characteristics and institutional development compared to developed countries. The structure of the banking market in America is more concentrated, whereas banks in Europe are generally separated into savings banks and investment banks, thus, differences in characteristics that can affect the performance of banks, including the banking industry in Indonesia which have a type of commercial bank and BPR. Based on the SCP hypothesis, the results of previous researches and logical thinking that have been explained above, this research formulates the hypothesis, as follows: $\mathrm{H}_{1}$ : market concentration has a positive effect on bank performance, and $\mathrm{H}_{2}$ : market share has a positive effect on bank performance. 
Furthermore, referring to the traditional view, the high market concentration will reduce the cost of collision and increase tacit or explicit collusion so that all companies in the market will get monopoly rent (Smirlock, 1985). In the oligopolistic market, collusion will encourage anti-competitive behavior among dominant companies to share markets to be able to enlarge its market share even without being accompanied by superior efficiency. It is feared that this collusion will get rid of small companies and make the market more concentrated so that only large companies benefit and will also harm consumers. This means that in the banking industry, large banks work together and share markets, creating anti-competitive conditions among large banks.

Following this, Rhoades (1982) refers to previous research on monopolies that occur in the manufacturing industry in America which results in welfare loss. These findings show indications of monopoly problems and prove that there is a positive and linear relationship between market structure and company performance. Rhoades (1982) examines estimates of welfare loss, distributional effects and restriction in loan output caused by monopolies in commercial banking. This is important because the banking industry is unique (intermediary institutions), it can provide important input (credit) to other industries economically so that the influence of monopoly in the banking industry has an important and systemic impact. Rhoades (1982) finds that welfare loss in the banking industry is very small, but the redistribution effect (total monopoly profits) and restriction of output in the banking industry are quite large. This shows that the collusive behavior in the banking industry allows the monopolization of profits by dominant banks, even though the impact of welfare loss found is not too large.

Irawati (2017) states that this collusive behavior can be seen from the positive interactions of the dominant banks as indicated by the positive interaction between market concentration and market share on bank performance. Market share is used as a moderating variable on the relationship between market concentration and bank performance. However, research of Irawati (2017) regarding collusive behavior in the SCP hypothesis in the national banking industry in Indonesia is not proven. On the contrary, these dominant banks do not use their market power to gain supernormal profits so that the dominance of large banks does not cause social welfare loss. Even so, in narrower market areas such as the regional level (regency and city) there is the potential for this collusive behavior to occur by dominant banks. So that further analysis is needed regarding the effect of market concentration and bank performance with market share as a moderating variable in a more specific market.

Several previous kinds of research support the SCP hypothesis and find that there are collusive behaviors from dominant banks through the use of market power to dominate the market, there are Heggestad \& Mingo (1976); Rhoades (1982); Short (1979). Based on the SCP hypothesis, the results of previous researches and logical thinking that have been explained above, this research formulates a hypothesis namely $\mathrm{H}_{3}$ : Market share strengthens the effect of market concentration on bank performance.

This research aims to analyze the relationship of market structure to bank performance and to examine the alleged collusive behavior by large banks. In contrast to other previous 
researches, market concentration and market share in this research uses banking data (commercial banks and BPR) in the regency/city level and uses all major components of banks (Interest Income/IINC, Third Party Funds/TPF, Assets/ASSET, Loans/LOAN). Besides, the role of market share, as a moderating variable, will be used to test the alleged collusive behavior by large banks. Finally, bank performance will be measured using the Return on Assets (ROA).

Based on the research background and problem statement before, this research will answer: (1) Does market concentration have a positive effect on bank performance?; (2). Does market share have a positive effect on bank performance?; and (3) Does market share strengthens the effect of market concentration on bank performance?. The benefit of this research is to provide empirical evidence and literature on the relationship between market structure and bank performance in the banking industry at the regional level, where commercial banks and rural banks are in the same market. Also, this research is expected to provide practical benefits for policymakers and banking industry players in Indonesia in formulating and evaluating industrial and banking policies, to be able to encourage industrial and banking performance. One of the policies that can be done is to encourage the consolidation of small BPR through the merger of regional government-owned BPR. This also applies to small commercial banks so that they can strengthen the capital of small banks to compete with large banks.

\section{METHOD}

The population in this research are all banks, commercial banks and rural banks, which were found in Central Java during 2012-2016. The research sample was selected using the purposive sampling method by eliminating regencies/cities with several banks under three banks.

Table 1. Sample Selection Process Based on Criteria

\begin{tabular}{|c|c|c|c|c|}
\hline No & Criteria & Commercial Bank & BPR & Total Bank \\
\hline 1 & $\begin{array}{l}\text { Number of banks in regencies/cities in } \\
\text { Central Java in 2012-2016 }\end{array}$ & 304 & 261 & 565 \\
\hline 2 & $\begin{array}{l}\text { The number of banks in regencies/cities } \\
\text { in Central Java that had less than three } \\
\text { banks in 2012-2016 }\end{array}$ & (1) & (1) & $(2)$ \\
\hline \multicolumn{3}{|c|}{ Number of final samples } & & 563 \\
\hline \multicolumn{4}{|c|}{ Year of observation } & 5 \\
\hline \multicolumn{4}{|c|}{ Number of observations } & 2815 \\
\hline
\end{tabular}

Based on Table 1, a final sample of 563 banks was obtained, spread into 34 regencies/cities in Central Java. There is one regency/city that was omitted because it did not fit the criteria, Pekalongan Regency (only having one commercial bank and one BPR).

The type of data in this research is panel data, which is a combination of cross-section and time-series data. The data source used is secondary data obtained from the bank's annual financial reports from the OJK website www.ojk.go.id, which contains data for research variables: ROA, CR, MS, OWN, EFF, SIZE, and TYPE. While the 
macroeconomic data, Gross Regional Domestic Product (GRDP), was obtained from the Central Bureau Statistics (BPS) of Central Java website www.jateng.bps.go.id.

To find out market concentration, market share, and bank performance, this research uses the following proxies:

Table 2. Definition and Operational Research Variables

\begin{tabular}{|c|c|c|}
\hline Variable & Proxy & Indicator \\
\hline \multicolumn{3}{|l|}{ DEPENDENT $(Y)$} \\
\hline \multirow[t]{2}{*}{ Bank Performance } & $\mathrm{ROA}$ & Net profit before taxes \\
\hline & & Total assets \\
\hline \multicolumn{3}{|l|}{ INDEPENDENT $(X)$} \\
\hline \multirow[t]{2}{*}{ Market Concentration } & CR3 & \\
\hline & HHI & \\
\hline \multicolumn{3}{|l|}{ MODERATION (Z) } \\
\hline \multirow[t]{2}{*}{ Market Share } & MS & Amount of IINC,TPF, ASSET, LOAN per bank \\
\hline & & Amount of INC,TPF, ASSET, LOAN of all banks \\
\hline \multicolumn{3}{|l|}{ CONTROL } \\
\hline Bank Ownership & OWN & $1=$ state-owned bank, $0=$ private owned bank \\
\hline Bank Operational & EFF & Bank operational expenses \\
\hline \multicolumn{2}{|l|}{ Efficiency } & Bank operating income \\
\hline Bank Size & SIZE & Ln(total assets $)$ \\
\hline Bank Type & TYPE & $1=\mathrm{BPR}, 0=$ commercial bank \\
\hline \multirow[t]{2}{*}{ Macroeconomic } & GRDP & GRDP regency/city \\
\hline & & GRDP province \\
\hline
\end{tabular}

Secondary data from the annual financial reports will be processed and analyzed using panel data regression using the STATA 14 program. The form of the research equation is as follows:

Yit $=\alpha+\beta 1 X i t+\beta 2 Z i t+\beta 3 X^{*}$ Zit $+\beta 4 \sum$ Controls $+\varepsilon$ it

\section{FINDING AND DISCUSSION}

Descriptive statistics test results show that market concentration in the three largest banks (CR3) at the regency/city level has a mean value of 62-70 percent with minimum and maximum value of 30-43 percent and 98-99 percent. While the mean value of HHI is 20952488 with a minimum value of 592-1038 and 5434-6850 for all major components of the bank (Interest Income/IINC, Third Party Funds/TPF, Assets/ASSET, Loans/LOAN). Based on PKPPU No. 02/2013, The Commission for The Supervision of Business Competition (KPPU) categorizes the level of market concentration based on HHI value into 
two spectra: Spectrum I (low concentration) with HHI value $<1800$, and Spectrum II (high concentration) with HHI value $>1800$. By the HHI value is 2095-2488, the market is categorized as Spectrum II or high concentration (KPPU, 2013). While categorizing the market based on concentration ratios, especially CR4, CR3 value of 62-70 percent can be categorized as a high oligopoly (CR4 values range between 50-75 percent).

Furthermore, the market share has a mean value of 6 percent of the total industry in each regency/city with a minimum value of 0 percent and a maximum value of $68-80$ percent based on all major components of the bank (IINC, TPF, ASSET, LOAN). This shows that the average market share of each bank (individual market share) at the regency/city level is relatively small, only a few banks that individually have a dominant market share of $68-80$ percent.

While bank performance indicated by the ROA variable has a mean value of 6 percent with a minimum value of -61 percent and a maximum value of 53 percent. This shows that individually, the bank's financial performance is low but still positive. Descriptive statistics test results on the control variables: OWN, EFF, SIZE, TYPE, and GDRP, can be seen in Table 3.

Table 3. Descriptive Statistics Test

\begin{tabular}{|c|c|c|c|c|c|}
\hline Variable & Obs. & Mean & Std. Dev. & Min & Max \\
\hline ROA & 2616 & 0.0611776 & 0.0665586 & -0.61 & 0.53 \\
\hline CR3 $3_{\text {IINC }}$ & 2815 & 0.6571408 & 0.2265749 & 0.3261383 & 0.9993162 \\
\hline $\mathrm{CR} 3_{\mathrm{TPF}}$ & 2815 & 0.6554518 & 0.2323353 & 0.3556158 & 0.99551 \\
\hline CR3 $3_{\text {ASSET }}$ & 2815 & 0.7055172 & 0.1824878 & 0.4330669 & 0.99535 \\
\hline CR3 $3_{\text {LOAN }}$ & 2815 & 0.627167 & 0.2353344 & 0.3066574 & 0.9838 \\
\hline $\mathrm{HHI}_{\text {IINC }}$ & 2815 & 0.2435334 & 0.1609629 & 0.0630813 & 0.6850543 \\
\hline $\mathrm{HHI}_{\mathrm{TPF}}$ & 2815 & 0. 2192714 & 01429234 & 0.0679887 & 0.5855487 \\
\hline $\mathrm{HHI}_{\mathrm{ASSET}}$ & 2815 & 0.2488643 & 0.1149295 & 0.1038171 & 0.5434083 \\
\hline $\mathrm{HHI}_{\text {LOAN }}$ & 2815 & 0.2095024 & 0.1337611 & 0.059227 & 0.5660359 \\
\hline $\mathrm{MS}_{\mathrm{IINC}}$ & 2619 & 0.0649115 & 0.1354593 & 0 & 0.8082234 \\
\hline $\mathrm{MS}_{\mathrm{TPF}}$ & 2679 & 0.0634565 & 0.1243005 & 0 & 0.7294557 \\
\hline $\mathrm{MS}_{\mathrm{ASSET}}$ & 2679 & 0.0634565 & 0.127152 & 0 & 0.7100655 \\
\hline $\mathrm{MS}_{\mathrm{LOAN}}$ & 2669 & 0.0636943 & 0.121605 & 0 & 0.6847224 \\
\hline OWN & 2815 & 0.3335702 & 0.471572 & 0 & 1 \\
\hline EFF & 2673 & 0.8640333 & 0.7123429 & -2.61 & 16.7 \\
\hline SIZE & 2678 & 22.54232 & 5.141653 & 14.26162 & 32.79575 \\
\hline TYPE & 2815 & 0.4618117 & 0.4986281 & 0 & 1 \\
\hline GRDP & 2815 & 0.0304653 & 0.0189421 & 0.0064 & 0.1046 \\
\hline
\end{tabular}

Market concentration and market share are measures of the market structure so that the relationship between the two variables is suspected of having a multicollinearity problem. Therefore, in the examination of $\mathrm{H}_{1}$ and $\mathrm{H}_{2}$ hypotheses, the two variables are not included in one equation model. However, to test the effect of moderation on the $\mathrm{H}_{3}$ hypothesis, the two variables will be included in one equation model. Also, the relationship 
between market share and bank size is suspected of having a multicollinearity problem so both need to be examined first. Correlation test results show that the correlation coefficient between independent variables, market concentration and market share, are around 0.300.34 shown in Table 4 (in bold).

Table 4. Correlation Test of Market Concentration and Market Share

\begin{tabular}{|c|c|c|c|c|c|c|c|c|}
\hline Variable & $\mathrm{CR} 3_{\text {IINC }}$ & $\mathrm{CR} 3_{\mathrm{TPF}}$ & CR3 $3_{\text {ASSET }}$ & $\mathrm{CR} 3_{\mathrm{LOAN}}$ & $\mathrm{HHI}_{\text {IINC }}$ & $\mathrm{HHI}_{\mathrm{TPF}}$ & $\mathrm{HHI}_{\mathrm{ASSET}}$ & $\mathrm{HHI}_{\text {LOAN }}$ \\
\hline CR3 $3_{\text {IINC }}$ & 1 & & & & & & & \\
\hline $\mathrm{CR} 3_{\mathrm{TPF}}$ & 0.979 & 1 & & & & & & \\
\hline CR $3_{\text {ASSET }}$ & 0.957 & 0.968 & 1 & & & & & \\
\hline CR3 $3_{\text {LOAN }}$ & 0.982 & 0.982 & 0.949 & 1 & & & & \\
\hline $\mathrm{HHI}_{\mathrm{IINC}}$ & 0.953 & 0.935 & 0.937 & 0.928 & 1 & & & \\
\hline $\mathrm{HHI}_{\mathrm{TPF}}$ & 0.938 & 0.968 & 0.948 & 0.939 & 0.939 & 1 & & \\
\hline $\mathrm{HHI}_{\mathrm{ASSET}}$ & 0.903 & 0.916 & 0.948 & 0.882 & 0.932 & 0.938 & 1 & \\
\hline $\mathrm{HHI}_{\text {LOAN }}$ & 0.935 & 0.940 & 0.920 & 0.960 & 0.934 & 0.935 & 0.884 & 1 \\
\hline $\mathrm{MS}_{\text {IINC }}$ & 0.316 & 0.305 & 0.304 & 0.316 & 0.306 & 0.291 & 0.292 & 0.307 \\
\hline $\mathrm{MS}_{\mathrm{TPF}}$ & 0.341 & 0.330 & 0.329 & 0.341 & 0.330 & 0.315 & 0.317 & 0.331 \\
\hline $\mathrm{MS}_{\mathrm{ASSET}}$ & 0.333 & 0.322 & 0.321 & 0.333 & 0.322 & 0.308 & 0.310 & 0.324 \\
\hline $\mathrm{MS}_{\mathrm{LOAN}}$ & 0.349 & 0.337 & 0.336 & 0.349 & 0.338 & 0.321 & 0.323 & 0.339 \\
\hline
\end{tabular}

Meanwhile, the correlation coefficient between market share and bank size in the range of $0.40-0.45$ is shown in Table 5 (in bold). It shows that there is no correlation coefficient which indicates a strong relationship between market share and bank size. Both correlation test results are below 0.55 or 0.75 , which indicates that there is no multicollinearity problem. Thus, market concentration, market share and bank size can be used in one equation model.

Table 5. Correlation Test of Market Share and Bank Size

\begin{tabular}{lrrrrr}
\multicolumn{1}{c}{ Variable } & \multicolumn{1}{c}{$\mathrm{MS}_{\text {IINC }}$} & \multicolumn{1}{c}{$\mathrm{MS}_{\text {TPF }}$} & \multicolumn{1}{c}{$\mathrm{MS}_{\text {ASSET }}$} & $\mathrm{MS}_{\text {LOAN }}$ & \multicolumn{1}{c}{ SIZE } \\
\hline $\mathrm{MS}_{\text {IINC }}$ & 1 & & & & \\
MS $_{\text {TPF }}$ & 0.937 & 1 & & & \\
MS $_{\text {ASSET }}$ & 0.847 & 0.919 & 1 & & \\
MS $_{\text {LOAN }}$ & 0.968 & 0.961 & 0.891 & $\mathbf{0 . 4 3 0}$ & 1 \\
\hline SIZE & $\mathbf{0 . 4 0 4}$ & $\mathbf{0 . 4 5 4}$ & $\mathbf{0 . 4 5 6}$ & \\
\hline
\end{tabular}

The first hypothesis testing is done by conducting a regression test on the relationship between market concentration and bank performance. Market concentration is measured by using CR3 and HHI based on IINC, TPF, ASSET, LOAN in the regency/city level while bank performance is measured by using ROA. In the formulation of the previous hypothesis, market concentration is expected to have a positive influence on bank 
performance, where high market concentration will improve bank performance. In general, the results show that there is a significant positive effect of CR3 and HHI on ROA.

Table 6. Random Effect Model Estimation Results

\begin{tabular}{|c|c|c|c|c|c|c|c|c|}
\hline & $\begin{array}{c}(1) \\
\text { ROA }\end{array}$ & $\begin{array}{c}(2) \\
\text { ROA }\end{array}$ & $\begin{array}{c}(3) \\
\text { ROA }\end{array}$ & $\begin{array}{c}(4) \\
\text { ROA }\end{array}$ & $\begin{array}{c}(5) \\
\text { ROA }\end{array}$ & $\begin{array}{c}(6) \\
\text { ROA }\end{array}$ & $\begin{array}{c}(7) \\
\text { ROA }\end{array}$ & $\begin{array}{c}(8) \\
\text { ROA }\end{array}$ \\
\hline $\begin{array}{l}\text { CR3 } 3_{\text {IINC }} \\
\text { CR3 } 3_{\text {TPF }} \\
\text { CR3 } 3_{\text {ASSET }} \\
\text { CR3 LOAN }\end{array}$ & $0.0502^{* * *}$ & $0.0466^{* * *}$ & $0.0503^{* * *}$ & $0.0482^{* * *}$ & & & & \\
\hline $\begin{array}{l}\text { HHI IINC }_{\text {IPF }} \\
\text { HHI }_{\text {TPF }} \\
\text { HHI }_{\text {ASSET }} \\
\text { HHI }_{\text {LOAN }}\end{array}$ & & & & & $0.0496^{* * *}$ & $0.0551^{* * *}$ & $0.0473^{*}$ & $0.0489^{* * *}$ \\
\hline OWN & $0.0155^{* *}$ & $0.0164^{* * *}$ & $0.0175^{* * *}$ & $0.0160^{* * *}$ & $0.0181^{* * *}$ & $0.0189^{* * *}$ & $0.0204^{* * *}$ & $0.0189^{* * *}$ \\
\hline EFF & $-0.0305^{* * *}$ & $-0.0305^{* * *}$ & $-0.0305^{* * *}$ & $-0.0306^{* * *}$ & $-0.0305^{* * *}$ & $-0.0306^{* * *}$ & $-0.0306^{* * *}$ & $-0.0306^{* * *}$ \\
\hline SIZE & $0.00284^{*}$ & $0.00285^{*}$ & $0.00275^{*}$ & $0.00249^{*}$ & $0.00282^{*}$ & $0.00275^{*}$ & $0.00261^{*}$ & $0.00227^{*}$ \\
\hline TYPE & $-0.0260^{*}$ & $-0.0260^{*}$ & $-0.0251^{*}$ & $-0.0297^{*}$ & -0.0226 & -0.0239 & -0.0223 & $-0.0284^{*}$ \\
\hline GRDP & 0.0651 & 0.0683 & 0.0230 & 0.0549 & 0.0212 & 0.0399 & 0.0122 & 0.0194 \\
\hline Constant & -0.000589 & 0.000909 & -0.000933 & 0.0110 & 0.0200 & 0.0206 & 0.0240 & 0.0325 \\
\hline Dummy year & YES & YES & YES & YES & YES & YES & YES & YES \\
\hline R-sq & 0.3664 & 0.3694 & 0.3663 & 0.3682 & 0.3632 & 0.3656 & 0.3591 & 0.3654 \\
\hline $\mathrm{N}$ & 2611 & 2611 & 2611 & 2611 & 2611 & 2611 & 2611 & 2611 \\
\hline
\end{tabular}

Table 6 shows that market concentration consistently has a significant positive effect on the level of $\alpha=1 \%$ : CR $3_{\text {IINC }}(0.0502), C R 3_{\text {TPF }}(0.0466), C R 3_{\text {ASSET }}(0.0503)$, and CR $3_{\text {LOAN }}$ (0.0482), while $\mathrm{HHI}_{\mathrm{IINC}}(0.0496), \mathrm{HHI}_{\mathrm{TPF}}(0.0551), \mathrm{HHI}_{\mathrm{LOAN}}(0.0489)$ and $\mathrm{HHI}_{\mathrm{ASSET}}(0.0473)$ on level of $\alpha=10 \%$. This result supports hypothesis 1 that market concentration has a positive effect on bank performance both when using CR3 and HHI as a measure of market concentration based on the four main components of the bank. This finding is consistent with previous researches such as Al-Muharrami \& Matthews (2009); Berger (1995); Berger \& Hannan (1989 \& 1997); Bhatti \& Hussain (2010); Nabieu (2013); Sathye (2005); Tregenna (2009) that high market concentration can improve bank performance following the SCP hypothesis.

Thus, a high market concentration gives a good effect for dominant banks to obtain higher profits in the market by utilizing their market power. The more concentrated market structure, the more positive bank performance will be. One of the things that can be done by banks is to increase the price of services to get a profit, so what needs to be considered is the concentration of the market causing the price to be less and less profitable for consumers. In highly concentrated markets, non-competitive behavior can be more beneficial for banks and detrimental to consumers (Berger \& Hannan, 1989).

Besides, positive significance on OWN and negative significance on TYPE shows that state-owned banks and commercial banks are found to be more profitable and perform better than private-owned banks and BPR when competing in the same market. This is reinforced by evidence that operational efficiency and bank size affect the ability of banks to obtain higher performance, which is indicated by the negative significance of the EFF and the positive significance of SIZE. In general, commercial banks have resources and management capabilities far above that of BPR so that when they meet in the same market, 
commercial banks will always be superior. The R-square value of model 1-8 in the range of 0.3591-0.3694 shows that the influence of the independent variable in explaining the dependent variable in the model is 36 percent, while 64 percent is explained by other variables not included in this research. Overall, the results of this first test support the $\mathrm{H}_{1}$ hypothesis that market concentration has a positive effect on bank performance.

The second hypothesis testing is to determine the effect of market share on bank performance. Market share is measured by using the ratio of market share (MS) of each bank to the total industry in the regency/city level based on four bank components, while bank performance is measured by using ROA. Table 7 shows that market share consistently has a significant positive effect on significant ROA at $\alpha=1 \%$ in the four main components of the bank, namely $\mathrm{MS}_{\text {IINC }}(0.213), \mathrm{MS}_{\mathrm{TPF}}(0.153), \mathrm{MS}_{\text {ASSET }}(0.0991)$, and $\mathrm{MS}_{\mathrm{LOAN}}(0.243)$. R-square value of model $1-4$ in the range $0.3790-0.5354$ shows that the influence of independent variables in explaining the dependent variable in the model is 53 percent, while 47 percent is explained by other variables not included in this research.

These results are consistent with the findings of Smirlock (1985) who found a positive influence on the bank's market share on bank performance. If it is viewed from the perspective of market share as a signal of the efficiency of the company from Smirlock (1985), the domination of a large market share by dominant banks results in higher bank profits. One of the causes of a large market share is the ability of bank efficiency in operational activities.

These results indicate that the greater the market share of a bank, it will encourage banks to perform better and obtain higher profits (Garza-Garcia, 2012). It also reinforces the notion that banks with large market shares will continuously produce market power so that they become dominant banks and the market is increasingly concentrated, thus banks can obtain supernormal profits in the market. This is consistent with Short (1979) who supports the view that greater market power leads to higher levels of bank profits. One of the efforts of banks to obtain higher profits is by setting high price margins. This is consistent with the Relative Market Structure (RMP) hypothesis which predicts a positive relationship between market share and prices. Also, large banks can enjoy market power in many ways, such as providing good distribution to their branches, providing easy access for customers, providing quality financial services for customers, and providing good advertising to attract new customers (González et al., 2019).

On the contrary, banks with small market share find it difficult to expand market share in limited operational areas, such as regency/city. This result successfully supports hypothesis 2 that market share has a positive effect on bank performance. The greater the bank's market share, the more the bank's performance improves. Besides, these results indicate that operational efficiency (EFF) and type of commercial banks (TYPE) are the main factors of banks in encouraging and enlarging their market share, while government ownership (OWN) has not consistently had a positive effect on all aspects that may be caused by private banks having better operational efficiency capabilities. Meanwhile, the size of the company (SIZE) is also unable to show a positive effect. This proves that even 
though the bank has a large size if it is not followed by good operational efficiency, it will not be able to contribute to increasing market share and improving bank performance. Large market share is caused by superior efficiency compared to other competitors so that the positive relationship between market share and bank performance is inseparable from company efficiency. Overall, the results of this second test support the $\mathrm{H}_{2}$ hypothesis that market share has a positive effect on bank performance.

Table 7. Random Effect Model Estimation Results

\begin{tabular}{lcccc} 
& $(1)$ & $(2)$ & $(3)$ & $(4)$ \\
& ROA & ROA & ROA & ROA \\
\hline $\begin{array}{l}\text { MS }_{\text {IINC }} \\
\text { MS }_{\text {TPF }}\end{array}$ & $0.213^{* * *}$ & & & \\
MS $_{\text {ASSET }}$ & & $0.153^{* * *}$ & & \\
MS $_{\text {LOAN }}$ & & & $0.0991^{* * *}$ & $0.243^{* * *}$ \\
\hline OWN & 0.00648 & $0.00930^{*}$ & $0.0148^{* *}$ & -0.00101 \\
\hline EFF & $-0.0515^{* * *}$ & $-0.0306^{* * *}$ & $-0.0306^{* * *}$ & $-0.0296^{* * *}$ \\
\hline SIZE & $-0.00496^{* *}$ & -0.000796 & -0.000199 & -0.00146 \\
\hline TYPE & $-0.0779^{* * *}$ & $-0.0397^{*}$ & $-0.0379^{*}$ & $-0.0422^{* *}$ \\
\hline GRDP & 0.117 & 0.0673 & 0.0338 & 0.113 \\
\hline Constant & $0.235^{* * *}$ & $0.111^{*}$ & $0.0993^{*}$ & $0.122^{* *}$ \\
\hline Dummy year & YES & YES & YES & YES \\
\hline R-sq & 0.5354 & 0.4286 & 0.3790 & 0.4644 \\
\hline $\mathrm{N}$ & 2555 & 2611 & 2611 & 2608 \\
\hline
\end{tabular}

The third test was conducted to determine the effect of market share on the relationship between market concentration and bank performance or the role of market share as a moderating variable. This test is carried out to prove the existence of an interaction between market concentration and market share that is expected to reflect the collusive behavior between dominant banks to maintain and enlarge market share and to collect supernormal profits in the market together. In this test, the moderating interaction variable is added in the form of multiplication between CR3 and HHI with MS respectively based on IINC, TPF, ASSET, LOAN. Estimation results can be seen in Table 9.

Previously, testing was conducted to see how the relationship between market structure variables when tested in one model without the interaction of the two market concentration and market share as a moderator. The test results are shown in Table 8.

The results show that the positive effect of the market concentration on bank performance weakens and disappears when entering the market share into the model, while the market share is consistently found to have a significant positive effect on the level of $\alpha$ $=1 \%$ on bank performance. This means that the influence of market share in improving bank performance is more dominant than the effect of market concentration. Market concentration was only found to be significantly weaker in the CR $3_{\text {ASSET }}$ asset market (0.0276). The individual market share of the bank can eliminate the positive effect of market concentration. These results indicate that the collusive behavior among large banks may not be proven so that further investigation is needed by interacting market concentration and 
market share as a moderating variable. Significant positive coefficients on market share indicate that banks individually can compete in a concentrated market. However, banks with large market share still have dominant performance because they can utilize their market power to implement higher price margins and wider service distribution to obtain greater profits than other banks in the market (Garza-Garcia, 2012; González et al., 2019; Short, 1979; Smirlock, 1985).

Table 8. Random Effect Model Estimation Results without Moderation

\begin{tabular}{|c|c|c|c|c|c|c|c|c|}
\hline & $\begin{array}{c}(1) \\
\text { ROA }\end{array}$ & $\begin{array}{c}(2) \\
\text { ROA }\end{array}$ & $\begin{array}{c}(3) \\
\text { ROA }\end{array}$ & $\begin{array}{c}(4) \\
\text { ROA } \\
\end{array}$ & $\begin{array}{c}(5) \\
\text { ROA } \\
\end{array}$ & $\begin{array}{c}(6) \\
\text { ROA } \\
\end{array}$ & $\begin{array}{c}(7) \\
\text { ROA }\end{array}$ & $\begin{array}{c}(8) \\
\text { ROA }\end{array}$ \\
\hline CR3IINC & -0.00288 & & & & & & & \\
\hline $\mathrm{MS}_{\text {IINC }}$ & $0.215^{\star * *}$ & & & & & & & \\
\hline CR3 $3_{\mathrm{TPF}}$ & & 0.0106 & & & & & & \\
\hline $\mathrm{MS}_{\mathrm{TPF}}$ & & $0.143^{* * *}$ & & & & & & \\
\hline CR3 ASSET & & & $0.0276^{*}$ & & & & & \\
\hline $\mathrm{MS}_{\mathrm{ASSET}}$ & & & $0.0790^{* *}$ & & & & & \\
\hline CR3 LOAN & & & & -0.0102 & & & & \\
\hline $\mathrm{MS}_{\mathrm{LOAN}}$ & & & & $0.254^{* * *}$ & & & & \\
\hline $\mathrm{HHI}_{\text {IINC }}$ & & & & & -0.0178 & & & \\
\hline $\mathrm{MS}_{\text {IINC }}$ & & & & & $0.221^{\star * *}$ & & & \\
\hline $\mathrm{HHI}_{\mathrm{TPF}}$ & & & & & & 0.00223 & & \\
\hline $\mathrm{MS}_{\mathrm{TPF}}$ & & & & & & $0.152^{* * *}$ & & \\
\hline HHI ASSET & & & & & & & 0.0149 & \\
\hline $\mathrm{MS}_{\text {ASSET }}$ & & & & & & & $0.0924^{* *}$ & \\
\hline $\mathrm{HHI}_{\text {LOAN }}$ & & & & & & & & -0.0194 \\
\hline $\mathrm{MS}_{\text {LOAN }}$ & & & & & & & & $0.254^{* * *}$ \\
\hline OWN & 0.00686 & 0.00838 & $0.0128^{* *}$ & -0.000165 & $0.00822^{*}$ & $0.00920^{*}$ & $0.0141^{* *}$ & -0.000149 \\
\hline EFF & $-0.0515^{* * *}$ & $-0.0305^{* * *}$ & $-0.0305^{* * *}$ & $-0.0296^{* * *}$ & $-0.0516^{* * *}$ & $-0.0306^{* * *}$ & $-0.0306^{* * *}$ & $-0.0296^{* * *}$ \\
\hline SIZE & $-0.00505^{* *}$ & -0.000400 & 0.000703 & -0.00175 & $-0.00546^{* *}$ & -0.000736 & 0.000175 & -0.00175 \\
\hline TYPE & $-0.0780^{* * *}$ & $-0.0390^{*}$ & $-0.0354^{*}$ & $-0.0420^{* *}$ & $-0.0796^{* * *}$ & $-0.0396^{*}$ & $-0.0362^{*}$ & $-0.0420^{* *}$ \\
\hline GRDP & 0.113 & 0.0830 & 0.0495 & 0.102 & 0.104 & 0.0692 & 0.0425 & 0.104 \\
\hline Constant & $0.238^{* * *}$ & 0.0952 & 0.0605 & $0.134^{* *}$ & $0.250^{* * *}$ & $0.109^{*}$ & 0.0872 & $0.132^{* *}$ \\
\hline Dummy year & YES & YES & YES & YES & YES & YES & YES & YES \\
\hline R-sq & 0.5357 & 0.4276 & 0.3825 & 0.4656 & 0.5362 & 0.4285 & 0.3804 & 0.4655 \\
\hline $\mathrm{N}$ & 2555 & 2611 & 2611 & 2608 & 2555 & 2611 & 2611 & 2608 \\
\hline
\end{tabular}

Furthermore, the result of the interaction between market concentration and market share is shown in Table 9 as follows:

The results show that all the positive significance of CR3 and HHI disappears when entering $\mathrm{MS}$ and the interaction of $\mathrm{CR} 3{ }^{*} \mathrm{MS}$ and $\mathrm{HHI}{ }^{*} \mathrm{MS}$ into the model together, whereas most MS are still consistently significantly positive. This shows that when market concentration and market share are in one model, the influence of market share is more dominant, thereby eliminating the effect of market concentration on bank performance directly. This result is following Irawati (2017) that finds no indication of collusive behavior among dominant banks in the market to seek supernormal profits.

Meanwhile, the direction of the interaction between market concentration and market share shows less consistent results. According to Irawati (2017) if the interaction is significantly positive then it is suspected that there is a collusive behavior among large banks. The interaction results showed significant negative coefficients on the interaction of $\mathrm{CR}^{*} \mathrm{MS}_{\text {IINC }}(-0.500), \mathrm{CR}^{*} \mathrm{MS}_{\text {LOAN }}(-0.259), \mathrm{HHI}^{*} \mathrm{MS}_{\text {IINC }}(-0.343), \mathrm{HHI} * \mathrm{MS}_{\mathrm{TPF}}(-0.177)$, and $\mathrm{HHI}^{*} \mathrm{MS}_{\text {LOAN }}(-0.294)$, while the others are not significant as shown in Table 9. The R- 
square value of model 1-8 in the range 0.3792-0.5441 shows that the influence of the independent variable in explaining the dependent variable in the model is 54 percent, while 46 percent is explained by other variables not included in this research.

Table 9. Random Effect Model Estimation Results with Moderation

\begin{tabular}{|c|c|c|c|c|c|c|c|c|}
\hline & $\begin{array}{c}(1) \\
\text { ROA }\end{array}$ & $\begin{array}{c}(2) \\
\text { ROA }\end{array}$ & $\begin{array}{c}(3) \\
\text { ROA }\end{array}$ & $\begin{array}{c}(4) \\
\text { ROA }\end{array}$ & $\begin{array}{c}(5) \\
\text { ROA }\end{array}$ & $\begin{array}{c}\text { (6) } \\
\text { ROA }\end{array}$ & $\begin{array}{c}(7) \\
\text { ROA }\end{array}$ & $\begin{array}{c}\text { (8) } \\
\text { ROA }\end{array}$ \\
\hline CR3 IINC & 0.00919 & & & & & & & \\
\hline MS IINC & $0.676^{* * *}$ & & & & & & & \\
\hline $\mathrm{CR}^{*}{ }^{*} \mathrm{MS}_{\text {IINC }}$ & $-0.500^{\star * \star}$ & & & & & & & \\
\hline CR3 & & 0.0120 & & & & & & \\
\hline $\mathrm{MS}_{\mathrm{TPF}}$ & & $0.205^{* *}$ & & & & & & \\
\hline $\mathrm{CR}^{*}{ }^{*} \mathrm{MS}_{\mathrm{TPF}}$ & & -0.0664 & & & & & & \\
\hline CR3 $3_{\text {ASSET }}$ & & & 0.0230 & & & & & \\
\hline $\mathrm{MS}_{\text {ASSET }}$ & & & -0.0284 & & & & & \\
\hline $\mathrm{CR}^{*}{ }^{*} \mathrm{MS}_{\text {ASSET }}$ & & & 0.119 & & & & & \\
\hline CR3 $3_{\text {LOAN }}$ & & & & -0.00402 & & & & \\
\hline $\mathrm{MS}_{\text {LOAN }}$ & & & & $0.484^{* * *}$ & & & & \\
\hline $\mathrm{CR}^{*}{ }^{*} \mathrm{MS}_{\text {LOAN }}$ & & & & $-0.259^{*}$ & & & & \\
\hline HHIIINC & & & & & -0.000189 & & & \\
\hline MS IINC $_{\text {IIN }}$ & & & & & $0.378^{* * *}$ & & & \\
\hline HHI*MS ${ }_{\text {IINC }}$ & & & & & $-0.343^{* * t}$ & & & \\
\hline $\mathrm{HHI}_{\mathrm{TPF}}$ & & & & & & 0.00905 & & \\
\hline $\mathrm{MS}_{\mathrm{TPF}}$ & & & & & & $0.223^{\star * *}$ & & \\
\hline $\mathrm{HHI}^{*} \mathrm{MS}_{\mathrm{TPF}}$ & & & & & & $-0.177^{*}$ & & \\
\hline HHI $_{\text {ASSET }}$ & & & & & & & 0.0195 & \\
\hline $\mathrm{MS}_{\text {ASSET }}$ & & & & & & & $0.124^{* *}$ & \\
\hline $\mathrm{HHI}^{*} \mathrm{MS}_{\mathrm{ASSET}}$ & & & & & & & -0.082 & \\
\hline $\mathrm{HHI}_{\text {LOAN }}$ & & & & & & & & -0.00812 \\
\hline MS $_{\text {LOAN }}$ & & & & & & & & $0.360^{* * *}$ \\
\hline $\mathrm{HHI}^{*} \mathrm{MS}_{\mathrm{LOAN}}$ & & & & & & & & $-0.294^{*}$ \\
\hline OWN & 0.00330 & 0.00795 & $0.0135^{* *}$ & -0.00125 & 0.00390 & 0.00789 & $0.0134^{* * *}$ & -0.00130 \\
\hline EFF & $-0.0507^{* * *}$ & $-0.0305^{* * * *}$ & $-0.0305^{* * *}$ & $-0.0295^{* * *}$ & $-0.0508^{* * * *}$ & $-0.0305^{* * *}$ & $-0.0305^{* * *}$ & $-0.0295^{* * *}$ \\
\hline SIZE & $-0.00619^{* * * *}$ & -0.000586 & 0.00092 & -0.00258 & $-0.00557^{* *}$ & -0.000978 & 0.000142 & -0.00229 \\
\hline TYPE & $-0.0870^{* * *}$ & $-0.0404^{*}$ & $-0.0334^{* *}$ & $-0.0491^{* *}$ & $-0.0807^{* * * t}$ & $-0.0415^{*}$ & $-0.0366^{* *}$ & $-0.0470^{* *}$ \\
\hline GRDP & 0.108 & 0.0821 & 0.0484 & 0.0990 & 0.117 & 0.0732 & 0.0450 & 0.108 \\
\hline Constant & $0.256^{* * *}$ & 0.0986 & 0.0584 & $0.151^{* *}$ & $0.246^{* * *}$ & $0.113^{*}$ & $0.0867^{*}$ & $0.143^{* *}$ \\
\hline Dummy year & YES & YES & YES & YES & YES & YES & YES & YES \\
\hline R-sq & 0.5441 & 0.4276 & 0.3869 & 0.4700 & 0.5426 & 0.4292 & 0.3792 & 0.4686 \\
\hline $\mathrm{N}$ & 2555 & 2611 & 2611 & 2608 & 2555 & 2661 & 2661 & 2608 \\
\hline
\end{tabular}

These results indicate that the alleged collusive behavior of large banks is not proven, however, the negative coefficient needs to be a concern. This seems to indicate a decline in the ability of dominant banks to take advantage of certain efficiency advantages because of the presence of other large competitors in the market. These results are consistent with the findings of Smirlock (1985) that find a significant negative interaction between market concentration and market share as well as a significant positive coefficient on market share on bank performance. It means the influence of market share on bank performance is more dominant than the effect of market concentration. When big banks face the market, banks are not able to take benefit of efficiency advantages, so they cannot optimally increase their individual market share. This might be due to other large banks having supernormal efficiency advantages so that they are still able to increase market share and obtain high profits. 
Overall, the $\mathrm{H} 3$ hypothesis is rejected that market share is not proven to strengthen the effect of market concentration on bank performance or indicative of collusive behavior among large banks to control their markets and obtain supernormal profits is not proven.

Dominant banks in the market do not use collusive power to increase their supernormal profits and/or dominate the market together. For example, large banks do not collude by setting high service prices (higher loan rates and lower deposit rates), so they do not result in social welfare loss (Irawati, 2017). Also, in Indonesia, there are Financial Services Authority (OJK) and The Commission for The Supervision of Business Competition (KPPU) so that the potential for collusive behavior of large banks can be avoided. This effort can take the form of bank mergers at small banks that have limited core capital and cooperation schemes between commercial banks and rural banks. Small banks, both rural banks and commercial banks, which have difficulty meeting the minimum capital requirement can be merged so that potential operational risks can be minimized. Also, the cooperation scheme between BPR and commercial banks can be in the form of BPR access in the payment system through the ATM network of commercial banks (Kontan.co.id, 2019). This is following Bank Indonesia Regulation No. 14/2/PBI/2012 on the Amendment to Bank Indonesia Regulation No. 11/11/PBI/2009 concerning Management of Card-Based Payment Instrument Activities (Bank Indonesia, 2012). Besides, according to Regulation of Member of the Board of Governors of Bank Indonesia No. 20/21/PADG/2018 regarding Report on the Administration of Card-Based Payment Instrument and Electronic Money Activities by Rural Credit Banks and Non-Bank Institutions (Bank Indonesia, 2018). Thus, fair competition in the banking industry is maintained and does not harm consumers.

\section{CONCLUSION}

This research aims to examine the effect of market structure, measured by using market concentration and market share, on the performance of commercial banks and rural banks in Central Java. In general, the results of this research support the first and second hypotheses that there is a positive effect of market concentration and market share on bank performance. The more concentrated market structure and the greater the bank's market share, the better the bank's performance. However, the third hypothesis is rejected, market share as a moderator is not proven to strengthen the effect of market concentration on bank performance. Alleged collusive behavior among dominant banks in the market as indicated by the positive interaction of market concentration and bank market share is not proven. The dominant bank does not conduct collusive behavior in the industry to improve its performance so that social welfare loss does not occur.

The theoretical contribution of the results of this research is to provide empirical evidence regarding the relationship of market structure and bank performance in the SCP hypothesis to the banking industry at the regional level where commercial banks and rural banks compete with one another. The practical contribution of the results of this research is that high market concentration and market share can improve bank performance in Indonesia. One effort that can be done by policymakers and companies is by consolidating 126 
banks, such as small commercial banks and rural banks owned by local governments, as in the merger of rural banks owned by the Cirebon Regency and West Sumatra Province Government (OJK, 2019b \& 2019c). This also applies to commercial banks, OJK can encourage the consolidation of commercial banks. As in POJK No. 41/POJK.03/2019 concerning Merger, Consolidation, Acquisition, Integration, and Conversion of Commercial Banks in article 2 paragraph (1), whereas other than based on bank initiatives, bank consolidation can be based on OJK supervision (OJK, 2019a). As for efforts to prevent the occurrence of collusive behavior by large banks, the regulator is expected to encourage rural banks and commercial banks to improve cooperation schemes in providing banking services to the public.

This research uses the SCP hypothesis which is only limited in explaining the direct relationship between market structure and bank performance, without looking at the role of bank behavior as an element of conduct. So that in the future, further testing is needed to test the SCP hypothesis more comprehensively, such as adding variables related to bank behavior: credit aggressiveness, prudential behavior, setting price margins, applying technology and so on.

\section{REFERENCES}

Ab-Rahim, R., \& Chiang, S. N. (2016). Market structure and performance of Malaysian banking industry. Journal of Financial Reporting and Accounting, 14(2), 158-177. https://doi.org/10.1108/jfra-11-2014-0086

Al-Muharrami, S., \& Matthews, K. (2009). Market power versus efficient-structure in Arab GCC banking. Applied Financial Economics, 19(18), 1487-1496. https://doi.org/10.1080/09603100902845478

Bain, J. S. (1951). Relation of profit rate to industry concentration: American manufacturing, 1936-1940. Quarterly Journal of Economics, 65(3), 293-324. https://doi.org/10.2307/1882217

Bank Indonesia. (2012). Peraturan Bank Indonesia No. 14/2/PBI/2012 tentang Perubahan atas Peraturan Bank Indonesia No. 11/11/PBI/2009 tentang Penyelenggaraan kegiatan alat pembayaran dengan menggunakan kartu. Retrieved from https://www.bi.go.id/elicensing/helps/PBI 14.2.2012 - APMK.pdf

Bank Indonesia. (2018). Peraturan Anggota Dewan Gubernur No. 20/21/PADG/2018 tentang Laporan penyelenggaraan kegiatan alat pembayaran dengan menggunakan kartu dan uang elektronik (electronic money) oleh Bank Perkreditan Rakyat dan lembaga selain bank. Retrieved from https://www.bi.go.id/id/peraturan/moneter/Documents/PADG_202118.pdf

Berger, A. N. (1995). The profit-structure relationship in banking: Tests of market-power and efficient-structure hypotheses. Journal of Money, Credit and Banking, 27(2), 404. https://doi.org/10.2307/2077876

Berger, A. N., \& Hannan, T. H. (1989). The price-concentration relationship in banking. The Review of Economics and Statistics, 71(2), 291. https://doi.org/10.2307/1926975 
Berger, A. N., \& Hannan, T. H. (1997). Using efficiency measures to distinguish among alternative explanations of the structure-performance relationship in banking. Managerial Finance, 23(1), 6-31. https://doi.org/10.1108/eb018599

Bhatti, G. A., \& Hussain, H. (2010). Evidence on structure conduct performance hypothesis in Pakistani commercial banks. International Journal of Business and Management, 5(9), 174-187. https://doi.org/10.5539/ijbm.v5n9p174

Chaerani, N., Cotoro, M., \& Achmad, D. (2019). Struktur pasar dan kinerja: Studi kasus pada bank umum di Indonesia. Jurnal Riset Manajemen Dan Bisnis (JRMB) Fakultas Ekonomi UNIAT, 4(3), https://doi.org/https://doi.org/10.36226/jrmb.v4i3.276

375-384.

Demsetz, H. (1973). Industry structure, market rivalry, and public policy. The Journal of Law \& Economics, 16(1), 1-9. Retrieved from https://www.jstor.org/stable/724822

Deyoung, R., Hunter, W. C., \& Udell, G. F. (2004). The past, present, and probable future for community banks. Journal of Financial Services Research, 25(2-3), 85-133. https://doi.org/10.1023/b:fina.0000020656.65653.79

Garza-Garcia, J. G. (2012). Does market power influence bank profits in Mexico? A study on market power and efficiency. Applied Financial Economics, 22(1), 21-32. https://doi.org/10.1080/09603107.2011.595681

González, L. O., Razia, A., Búa, M. V., \& Sestayo, R. L. (2019). Market structure, performance, and efficiency: Evidence from the MENA banking sector. International Review of Economics \& Finance, 64, 84-101. https://doi.org/10.1016/j.iref.2019.05.013

Hafidz, Januar Sagita Rachmanira, O. T. (2013). Tingkat persaingan dan efisiensi bank umum dan BPR di pasar kredit mikro di Indonesia.

Heggestad, A. A., \& Mingo, J. J. (1976). Prices, nonprices, and concentration in commercial banking. Journal of Money, Credit and Banking, 8(1), 107. https://doi.org/10.2307/1991923

Irawati, D. (2017). Struktur pasar, efisiensi, dan kinerja perbankan Indonesia.

Komisi Pengawas Persaingan Usaha. (2013). PKPPU No. 02 tahun 2013 tentang Perubahan ketiga atas PKPPU No. 13 tahun 2010 tentang Pedoman pelaksanaan tentang penggabungan atau peleburan badan usaha dan pengambilalihan saham perusahaan yang dapat mengakibatkan terjadinya praktik monopoli dan per. Retrieved from https://www.kppu.go.id/docs/Merger/Perkom 02 Tahun 2013.pdf

Kontan.co.id. (2019). Bila ingin terbitkan kartu ATM, BPR mesti gandeng bank umum. Retrieved from https://keuangan.kontan.co.id/news/bila-ingin-terbitkan-kartu-atmbpr-mesti-gandeng-bank-umum

Mason, E. (1939). Price and production policies of large scale enterprises. American Economic Review, 39(1), 61-74.

Nabieu, G. A. A. (2013). The structure, conduct and performance of commercial banks in 
Ghana. European Journal of Business and Innovation Research, 1(4), 34-47.

Neuberger, D. (1997). Structure, conduct and performance in banking markets.

Otoritas Jasa Keuangan. (2017). Statistik Perbankan Indonesia Juni 2017.

Otoritas Jasa Keuangan. (2019a). POJK No. 41/POJK.03/2019 tentang Penggabungan, peleburan, pengambilalihan, integrasi, dan konversi bank umum. Retrieved from POJK nomor

41/POJK.03/2019\%0Ahttps://www.ojk.go.id/id/regulasi/Documents/Pages/Peng gabungan\%2C-Peleburan\%2C-Pengambilalihan\%2C-Integrasi\%2C--dan-KonversiBank-Umum/POJK 41-2019.pdf\%0A

Otoritas Jasa Keuangan. (2019b). Siaran pers OJK dorong konsolidasi BPR dan program ketahanan pangan di Sumatera Barat. Retrieved from https://ojk.go.id/id/berita-dankegiatan/siaran-pers/Documents/Pages/Siaran-Pers-OJK-Dorong-Konsolidasi-BPRdan-Program-Ketahanan-Pangan-di-Sumatera-Barat/SP - OJK DORONG KONSOLIDASI BPR DAN PROGRAM KETAHANAN PANGAN DI SUMATERA BARAT.pdf

Otoritas Jasa Keuangan. (2019c). Siaran pers OJK dorong penguatan BPR: Peresmian merger BPR di Kabupaten Cirebon. Retrieved from https://www.ojk.go.id/id/berita-dankegiatan/siaran-pers/Documents/Pages/Siaran-Pers-OJK-Dorong-PenguatanBPR/SP - OJK Dorong Penguatan BPR.pdf

Peltzman, S. (1977). The gains and losses from industrial concentration. The Journal of Law and Economics, 20(2), 229-263. https://doi.org/10.1086/466902

Rettab, B., Kashani, H., Obay, L., \& Rao, A. (2010). Impact of market power and efficiency on performance of banks in the Gulf Cooperation Council countries. International Research Journal of Finance and Economics, 50(February 2014), 190-203.

Rhoades, S. A. (1982). Welfare loss, redistribution effect, and restriction of output due to monopoly in banking. Journal of Monetary Economics, 9(3), 375-387. https://doi.org/10.1016/0304-3932(82)90024-1

Sathye, M. (2005). Market structure and performance in Australian banking. Review of Accounting and Finance, 4(2), 107-124. https://doi.org/10.1108/eb043425

Short, B. K. (1979). The relation between commercial bank profit rates and banking concentration in Canada, Western Europe, and Japan. Journal of Banking \& Finance, 3(3), 209-219. https://doi.org/10.1016/0378-4266(79)90016-5

Smirlock, M. (1985). Evidence on the (non) relationship between concentration and profitability in banking. Journal of Money, Credit and Banking, 17(1), 69. https://doi.org/10.2307/1992507

Tregenna, F. (2009). The fat years: The structure and profitability of the US banking sector in the pre-crisis period. Cambridge Journal of Economics, 33(4 SPEC. ISS.), 609-632. https://doi.org/10.1093/cje/bep025 